\title{
CORROSION BEHAVIOUR OF BRASS IN THE VEMBANAD ESTUARY, INDIA
}

Andy Mathiazhagan

Department of Ship Technology, Cochin University of Science and Technology, Kochi-682022, Kerala, India., alagan@cusat.ac.in

Rani Joseph

Department of Polymer Science and Rubber Technology, Cochin University of Science and Technology, Kochi-682022, Kerala, India.

Kanjiramparayil Puthilon Narayanan

Department of Polymer Science and Rubber Technology, Cochin University of Science and Technology, Kochi-682022, Kerala, India.

Palaniandy Seralathan

Department of Marine Geology and Geophysics, Cochin University of Science and Technology, Kochi-682022, Kerala, India

Follow this and additional works at: https://jmstt.ntou.edu.tw/journal

Part of the Transportation Engineering Commons

\section{Recommended Citation}

Mathiazhagan, Andy; Joseph, Rani; Puthilon Narayanan, Kanjiramparayil; and Seralathan, Palaniandy (2010) "CORROSION BEHAVIOUR OF BRASS IN THE VEMBANAD ESTUARY, INDIA," Journal of Marine Science and Technology. Vol. 18: Iss. 5, Article 12.

DOI: $10.51400 / 2709-6998.1921$

Available at: https://jmstt.ntou.edu.tw/journal/vol18/iss5/12

This Research Article is brought to you for free and open access by Journal of Marine Science and Technology. It has been accepted for inclusion in Journal of Marine Science and Technology by an authorized editor of Journal of Marine Science and Technology. 


\title{
CORROSION BEHAVIOUR OF BRASS IN THE VEMBANAD ESTUARY, INDIA
}

\author{
Andy Mathiazhagan*, Rani Joseph**, Kanjiramparayil Puthilon Narayanan*, and \\ Palaniandy Seralathan***
}

Key words: brass, corrosion products, estuary, Cochin.

\begin{abstract}
Corrosion characteristics of brass panels were investigated in the Vembanad estuarine water (Cochin Harbor), India over a period of one year. The corrosion rate of brass samples during exposure was determined by gravimetric method and fouling on panels was assessed, exposure-wise, in terms of biomass. Corrosion products were identified by X-Ray diffraction. The results of the study were discussed in the light of the seawater characteristics.
\end{abstract}

\section{INTRODUCTION}

Copper and its alloys are widely used in marine environments due to their corrosion resistance, mechanical workability, excellent electrical and thermal conductivities and good resistance to biofouling. Brass is used extensively in marine applications such as heat exchanger tubes, desalination and power generation plants.

The corrosion resistance of copper and copper alloys has been attributed to a protective cuprous oxide layer, $\mathrm{Cu}_{2} \mathrm{O}$, formed upon exposure. However, these alloys can deteriorate due to the formation of biofilm, whose polymeric structure allows local gradients of $\mathrm{pH}$ and $\mathrm{O}_{2}$ [2]. Also the dissolved organic matter and colloidal substances present in the natural seawater and polluted seawater may influence the corrosion behavior of brass. Although the microbiologically influenced corrosion of carbon steel and stainless steel has been widely studied, there has been little investigation on copper and copper alloys [1, 3-13]. Mansfeld and Little [9] concluded that copper alloys exposed to natural seawater (NSW) were colonized by bacteria within 3 weeks and that in all cases the corrosion rates in NSW

Paper submitted 03/12/09; revised 10/01/09; accepted 10/02/09. Author for correspondence: Andy Mathiazhagan (e-mail: alagan@cusat.ac.in).

*Department of Ship Technology, Cochin University of Science and Technology, Kochi-682022, Kerala, India.

**Department of Polymer Science and Rubber Technology, Cochin University of Science and Technology, Kochi-682022, Kerala, India.

***Department of Marine Geology and Geophysics, Cochin University of Science and Technology, Kochi-682022, Kerala, India. were higher than those in artificial seawater (ASW). Kharafi et al. [7] observed selective dissolution of brass at various potentials and chloride concentrations and concluded that chloride promotes the dissolution of copper and also zinc. Santos et al. $[12,13]$ in their study on the corrosion of brass in nondeoxygenated, non-buffered seawater solutions observed higher weight gain and corrosion rate on the brass sample immersed in NSW. Naguib and Mansfeld [10] studied the corrosion behavior of Aluminum 2024, mild steel and cartridge brass in artificial seawater (ASW) containing a growth medium contaminated by bacteria. Under sterilized conditions, they concluded that the corrosion behavior was similar to that in ASW without bacteria. Huang et al. [5] emphasized the importance of performing corrosion studies in NSW, under anaerobic conditions. Huang et al. [5] noticed that the sulfate reducing bacteria (SRB) attached on the alloy surface formed a biofilm and led to intergranular corrosion after 7 days of immersion in seawater containing sulfate reducing bacteria (SRB) and consequently, a significant decrease in the polarization resistance was observed. Under anoxic conditions, cathodic reactant may be $\mathrm{H}_{2} \mathrm{O}$ and/or organic compounds, or products from the microbial activity, particularly in NSW.

In order to conduct realistic corrosion tests, variation in sea water conditions must be taken into account [12]. In an estuarine area, there can be different salinity conditions due to variation of mixing of seawater with freshwater. Vembanad estuarine water is in a state of anoxic condition due to large quantity of organic carbon in the sediments with the presence of sulphite ions and/or ammonia. These factors can lead to quite different corrosion mechanisms, resulting in the formation of very different corrosion product layer compared to those formed in natural seawater. There is scanty information on the effect of the estuarine water on the corrosion behavior of brasses. As cochin harbor, which is situated in the Vembanad estuary, is an internationally known natural sea port for loading and unloading, it is felt that corrosion behavior of brass can be carried out in a natural condition. The testing was carried out for a period of one year.

\section{EXPERIMENTS}

The brass panels (65-35) with dimension of $5 \times 4 \mathrm{~cm}$ were 


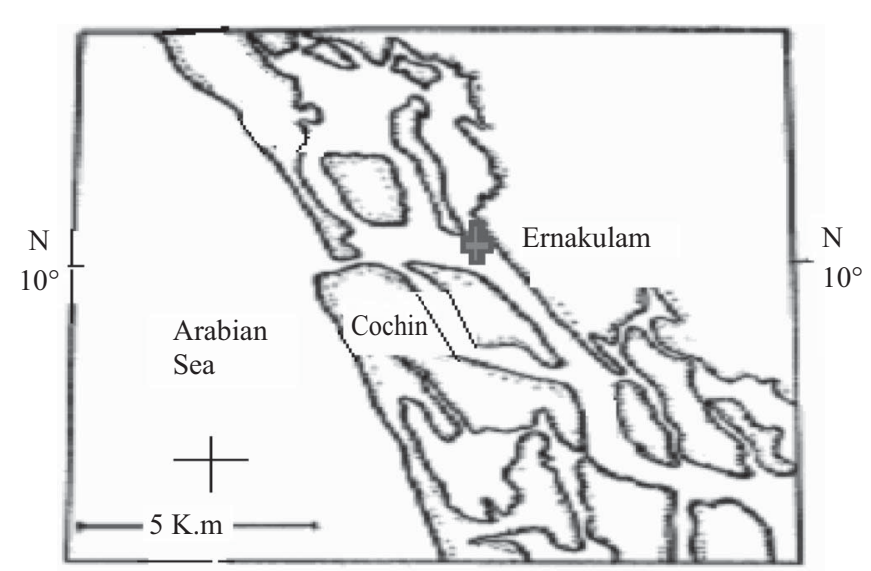

Fig. 1. Location of the test site (+) in the Vembanad estuary.

polished with emery paper, rinsed several times with distilled water, degreased with acetone, washed again with distilled water and dried. All panels were weighed and fixed on the fibreglass strips with PVC nuts and bolts. The panels in six replicates were deployed at the beginning of exposure period in Vembanad estuarine water near Cochin city, which is situated on the southwest coast of India and retrieved at the end of each exposure period for data collection. After retrieval the panels were first rinsed gently with sterile sea water to remove any non-adhering bacteria and diatoms. The difference between initial weight prior to deployment and final weight, after removal of corrosion products by standard method [6], was used to calculate corrosion rate using the following formula:

$$
\operatorname{mdd}=W /\left(A^{*} T\right)
$$

where mdd is corrosion rate expressed in terms of metal loss $(\mathrm{mg})$ [per decimeter square area per day], $W$ the loss in weight (mg), $A$ the area of panels $\left(\mathrm{dm}^{2}\right)$, and $T$ the exposure time (days).

Fouling on panels was assessed, exposure-wise, in terms of biomass. The biomass was calculated after scrapping the mass adhered on the metal surface and drying it in an air oven for an hour at $60^{\circ} \mathrm{C}$.

Water sample was collected from the study area at every month and analyzed for identifying the hydrochemical parameters such as salinity, dissolved oxygen, temperature and $\mathrm{pH}$. Salinity and temperature were recorded using a salinitytemperature bridge and the dissolved oxygen content was analyzed using Winkle's method and a portable $\mathrm{pH}$ meter was used to measure the $\mathrm{pH}$.

Surface of corroded brass samples after exposure periods were scrapped and dried at room temperature for 10 days. The corrosion products and biomass were finely powdered with a mortar and were examined with X-ray diffraction (Bruker AXS D8 Advance) for identifying the compounds of inorganic nature of oxides, chlorides, carbonates, hydroxides and oxychlorides of calcium, magnesium and iron.

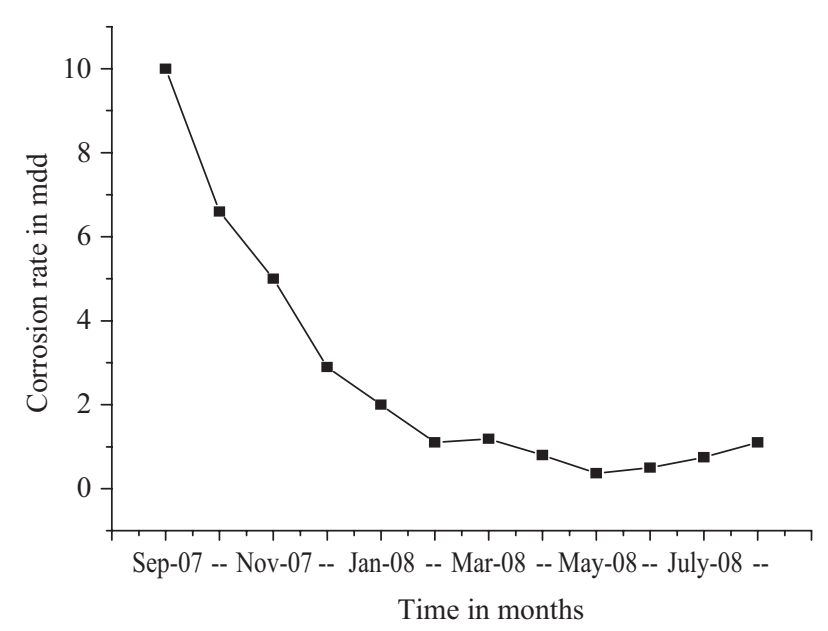

Fig. 2. Corrosion rate of brass samples in the Vembanad estuary for different exposure periods.

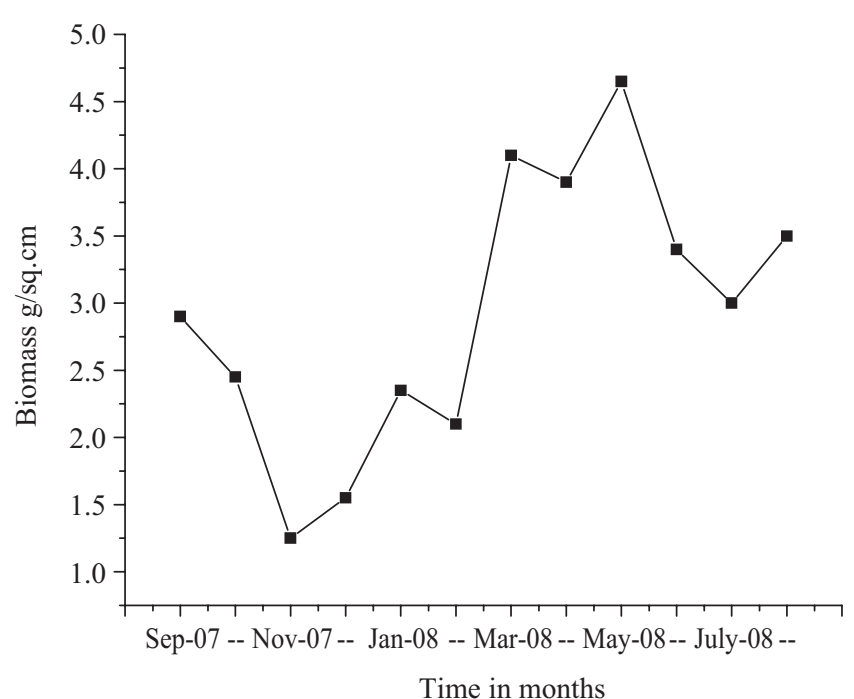

Fig. 3. Biomass settlement on brass samples in the Vembanad estuary for different exposure periods.

\section{RESULTS \& DISCUSSION}

\section{Corrosion Rate}

The variation of the corrosion rate versus time is plotted in Figs. 2 and 4. The corrosion rate is decided by various factors such as surface temperature of sea water, dissolved oxygen concentration, wave action, salinity, monsoon rain and settlement and growth of marine organisms. The corrosion rate decreased steadily up to ninth month exposure(Fig. 2) and the decrease of corrosion rate is related to the protecting film formed almost on brass panel. But the corrosion rate increased slightly after ninth month which is from June-08 onwards coinciding with the onset of monsoon. The slight increase of corrosion rate experienced by the brass is mainly attributed to the removal of protective film by turbulence caused through influx of rain water and soft fouler and micro and macro algae, 


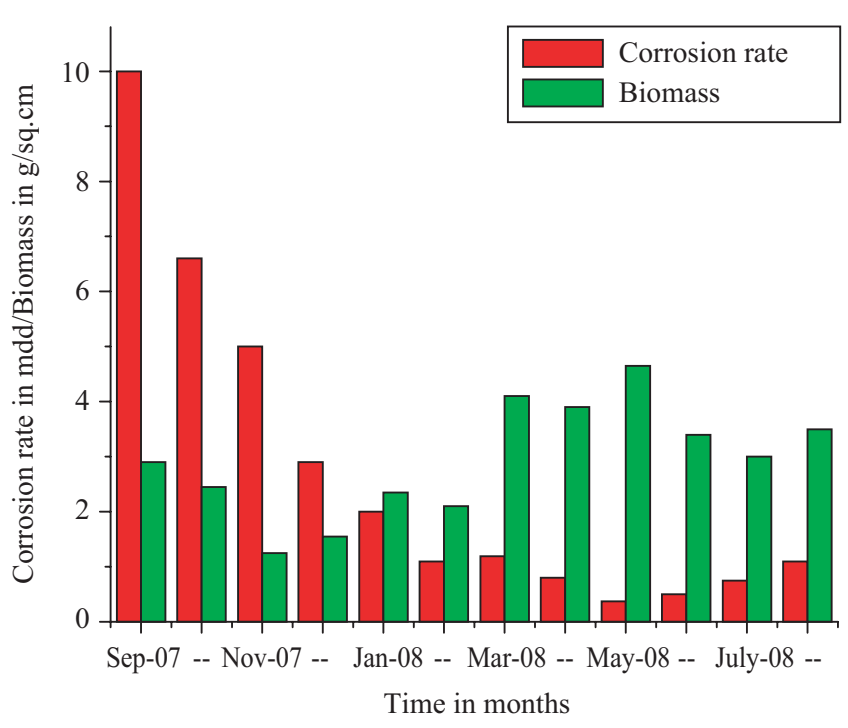

Fig. 4. Comparison of corrosion rate and biomass of brass samples with time in the Vembanad estuary.

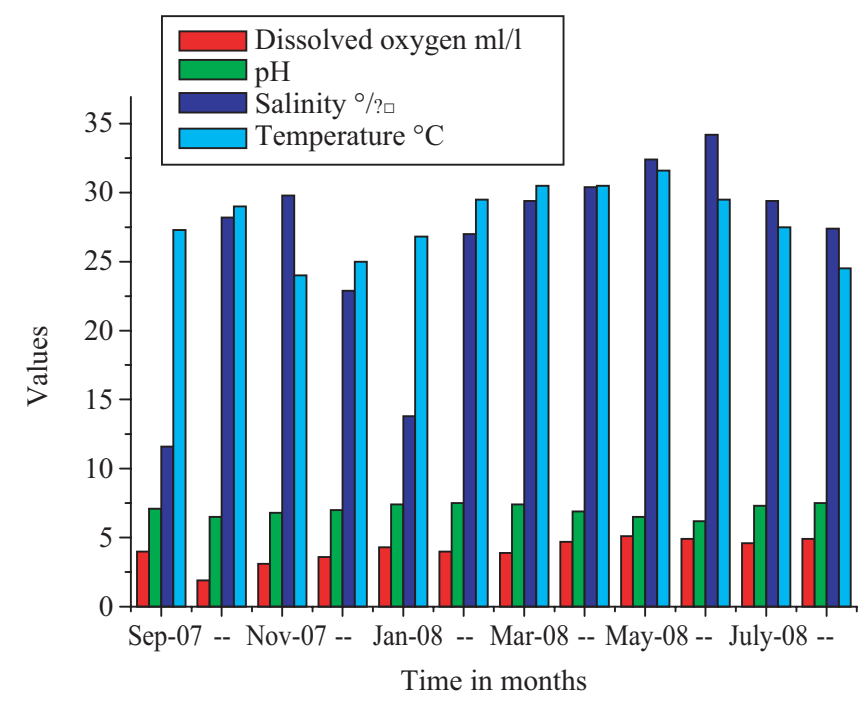

Fig. 5. Variation of dissolved oxygen, pH, salinity, temperature of water sample at each exposure from Vembanad estuary.

that fouled on brass. The exponential decrease in the corrosion rate of brass over the period of time implies the protective nature of corrosion products.

\section{Biomass}

The variation of the biomass versus time is plotted in Figs. 3 and 4 . The biomass on brass which was $2.9 \mathrm{~g} / \mathrm{cm}^{2}$ at 1 month got reduced drastically to $1.25 \mathrm{~g} / \mathrm{cm}^{2}$ at 3 month and thereafter the biomass increased up to $4.65 \mathrm{~g} / \mathrm{cm}^{2}$ at 9 month with small fluctuation (Fig. 3) in between. Settlement of fouling was low up to third exposure month as the salinity in this period (Fig. 5) and toxic effect of brass were increased and thereafter fouling was increased since hydro chemical parameter and toxic effect of brass were not significant on fouling. With prolonged
Table 1. XRD data of corrosion products of brass immersed in Vembanad estuary.

\begin{tabular}{|c|c|l|}
\hline No & $\begin{array}{c}\text { Exposure period } \\
\text { (Months) }\end{array}$ & Corrosion products \\
\hline 1 & 3 & $\begin{array}{l}\mathrm{CuCO}_{3} \cdot \mathrm{Cu}(\mathrm{OH})_{2}, \mathrm{Cu}-\mathrm{Zn}, \\
\mathrm{Zn}_{12}(\mathrm{OH})_{15} \mathrm{Cl}_{3}\left(\mathrm{SO}_{4}\right)_{3} \cdot 5 \mathrm{H}_{2} \mathrm{O}, \mathrm{Si} \\
2\end{array}$ \\
3 & 6 & $\begin{array}{l}\mathrm{CuCO}_{3} \cdot \mathrm{Cu}(\mathrm{OH})_{2}, \mathrm{Cu}-\mathrm{Zn}, \mathrm{Zn}_{12}(\mathrm{OH})_{15} \\
\mathrm{Cl}_{3}\left(\mathrm{SO}_{4}\right)_{3} \cdot 5 \mathrm{H}_{2} \mathrm{O} \\
\mathrm{CuCO}_{3} \cdot \mathrm{Cu}(\mathrm{OH})_{2}, \mathrm{Zn}_{12}(\mathrm{OH})_{15} \\
\mathrm{Cl}_{3}\left(\mathrm{SO}_{4}\right)_{3} \cdot 5 \mathrm{H}_{2} \mathrm{O}, \mathrm{Zn}_{4} \mathrm{SO}_{4}(\mathrm{OH})_{6} \cdot 4 \mathrm{H}_{2} \mathrm{O}\end{array}$ \\
\hline
\end{tabular}

exposure, the toxic effect of brass was reduced and thereby enhanced bio-adherence could occur.

\section{Corrosion Products}

X-ray powder pattern of the corrosion products formed on brass at each exposure months in Vembanad estuarine water is shown in Table 1. Different types of compounds were found on brass during the study period. The surface of corroded brass was characterized by the presence of $\mathrm{CuCO}_{3} \cdot \mathrm{Cu}(\mathrm{OH})_{2}, \mathrm{Cu}-\mathrm{Zn}$, $\mathrm{Zn}_{12}(\mathrm{OH})_{15} \mathrm{Cl}_{3}\left(\mathrm{SO}_{4}\right)_{3} .5 \mathrm{H}_{2} \mathrm{O}$, Si in third month exposure and $\mathrm{CuCO}_{3} . \mathrm{Cu}(\mathrm{OH})_{2}, \mathrm{Cu}-\mathrm{Zn}, \mathrm{Zn}_{12}(\mathrm{OH})_{15} \mathrm{Cl}_{3}\left(\mathrm{SO}_{4}\right)_{3} .5 \mathrm{H}_{2} \mathrm{O}$ in the sixth month exposure and $\mathrm{CuCO}_{3} \cdot \mathrm{Cu}(\mathrm{OH})_{2}, \mathrm{Zn}_{12}(\mathrm{OH})_{15}$ $\mathrm{Cl}_{3}\left(\mathrm{SO}_{4}\right)_{3} .5 \mathrm{H}_{2} \mathrm{O}, \mathrm{Zn}_{4} \mathrm{SO}_{4}(\mathrm{OH})_{6} \cdot 4 \mathrm{H}_{2} \mathrm{O}$ in the twelfth month exposure respectively. XRD data show that corrosion of brass was reduced considerably as corrosion products were formed on the metal surface during longer periods of exposure.

\section{Hydrochemical Parameters}

Variation in different hydrochemical parameters during the period of observation is presented in Fig. 5. Initially salinity was found to be $11.6 \%$ on first month exposure and increased to maximum of $29.8 \%$ on third month exposure then it was reduced to $13.8 \%$ on fifth month exposure and again increased to $34.2 \%$ on tenth month exposure and afterwards it reduced to $27.4 \%$ on twelfth due to fresh water influx during the monsoon period. Salinity in marine atmospheric condition accelerates metallic corrosion (15). Temperature was initially $27.3^{\circ} \mathrm{C}$ which increased to $29.0^{\circ} \mathrm{C}$ on second month and reduced to $24^{\circ} \mathrm{C}$ on third month exposure and then increased to maximum of $31.6^{\circ} \mathrm{C}$ on ninth month exposure and after that there was drop in the temperature to $24.5^{\circ} \mathrm{C}$ on twelfth month due to influx of freshwater during the monsoon period. Dissolved oxygen was $4 \mathrm{ml} / \mathrm{l}$ at the first month exposure and reduced to $1.9 \mathrm{ml} / \mathrm{l}$ on second month and then increased to maximum of $5.1 \mathrm{ml} / \mathrm{l}$ on ninth month exposure with small fluctuation in between and afterward reduced to $4.6 \mathrm{ml} / \mathrm{l}$ on eleventh month while increased to $4.9 \mathrm{ml} / \mathrm{l}$ at the end of exposure period. $\mathrm{pH}$ of the water was 7.1 on exposure of sample and reduced to 6.5 on second month and again increased to 7.5 on sixth month exposure and then reduced to 6.2 on tenth month exposure and after that increased to 7.5 on twelfth month exposure. It is reported that the microbial activity may 
contribute to lower the $\mathrm{pH}$ (14). There was no much variation of dissolved oxygen and $\mathrm{pH}$ of estuarine water of Vembanad with regard to exposure period and therefore these data could not be correlated to corrosion of brass. But settlement of organisms was influenced by the salinity and temperature.

\section{CONCLUSION}

The corrosion rate of brass in the Vembanad estuarine water tends to lower during longer exposure periods due to formation of protective layer. Fouling was less in the initial period of exposure and increased during prolonged exposure due to lower leaching of toxic cuprous ions.

XRD data show that the Vembanad estuarine water significantly affects the nature of the crystalline corrosion products which could be responsible for the passivity of brass.

There was no much variation of dissolved oxygen and $\mathrm{pH}$ of estuarine water of Vembanad with regard to exposure period and therefore these data could not be correlated to corrosion of brass. However, fouling on brass was influenced by the salinity and temperature of estuarine water.

\section{REFERENCES}

1. Bastos, M. C., Mendonca, M. H., Neto, M. M. G. S., Rocha Proenca, L., and Fonseca, I. T. E., "Corrosion of brass in natural and artificial sea water under anaerobic conditions," Journal of Applied Electrochemistry, Vol. 38, No. 5, pp. 627-635 (2008).

2. Blunn, G., Biological Fouling of Copper and Copper Alloys, Technical Report, International Mycological Institute and Bio deterioration Society, London (1986).

3. Efird, K. D. and Lee, T. S., "Putrid seawater as a corrosive medium,"
Journal of Corrosion, Vol. 35, No. 2, pp. 79-83 (1979).

4. Hostis, V. L., Dagbergt, C., and Feron, D., "Electrochemical behavior of metallic materials used in sea water," Journal of Electrochemical Acta, Vol. 48, No. 10, pp. 1451-1458 (2003).

5. Huang, G., Chan, K. Y., and Fang, H. H. P., "Microbiologically induced corrosion of $70 \mathrm{Cu}-3 \mathrm{Ni}$ alloy in anaerobic sea water," Journal of Electrochem Society, Vol. 151, No. 7, pp. B 434-439 (2004).

6. ISO/DIS 8407, "Metal and alloys procedure for the removal of the corrosion products from corrosion tests specimens," Geneve, Switzerland (1986).

7. Kharafi, F. C. M., Atheya, B. G., and Adb-Allah, R. M., "Selective dissolution of brass in salt water," Journal of Applied Electrochemistry, Vol. 34, No. 1, pp. 47-53 (2004)

8. Liu, J., Zhen, J., and Xu, L., "The corrosion behavior of 70/30 copperzinc alloy under the biofilm of sulfate-reducing bacteria," Journal of Material and Corrosion, Vol. 52, No. 11, pp. 833-837 (2001).

9. Mansfeld, F. and Little, B., "Microbiologically influenced corrosion of copper-based materials exposed to natural seawater," Journal of Electrochim Acta, Vol. 37, No. 12, pp. 2291-2297 (1992).

10. Nagiub, A. and Mansfeld, F., "Evaluation of microbiologically influenced corrosion inhibition with EIS and ENA," Journal of Electrochim Acta, Vol. 47, No. 13-14, pp. 2319-2333 (2002).

11. Neto, R. P. C., Cesar, A. C., and Sequeira, C. A., "Electrochemical impedance spectroscopy study of the biofilm related deterioration of aluminum bronze in sea water," Journal of Key Engineering Materials, Vol. 230, pp. 432-43 5(2002).

12. Santos, C. S., Corrosion of Brass, Master Thesis, University of Lisboa, Lisboa, Portugal (2005).

13. Santos, C. S., Mendonc, M. H., and Fonseca, I. T. E., "Corrosion of brass in natural and artificial seawater," Journal of Applied Electrochemistry, Vol. 36, No. 12, pp. 1353-1359 (2006).

14. Wang, Y. Z., Beccaria, A. M., and Poggi, G., "The effect of temperature on the corrosion behaviour of a $70 / 30 \mathrm{Cu}-\mathrm{Ni}$ commercial alloy in seawater," Journal of Corrosion Science, Vol. 36, No. 8, pp. 1277-1288 (1994).

15. Winston Revie, R., Uhlig's Corrosion Handbook, Second Edition, John Wiley and Sons Inc, U.S (2000). 